\title{
STRATEGIC HUMAN RESOURCE PRACTICES, TOP MANAGEMENT TEAM SOCIAL NETWORKS, AND FIRM PERFORMANCE: THE ROLE OF HUMAN RESOURCE PRACTICES IN CREATING ORGANIZATIONAL COMPETITIVE ADVANTAGE
}

\author{
CHRISTOPHER J. COLLINS \\ Cornell University \\ KEVIN D. CLARK \\ Villanova University
}

\begin{abstract}
In this article, we begin to explore the black box between human resources (HR) practices and firm performance. Specifically, we examine the relationships between a set of network-building HR practices, aspects of the external and internal social networks of top management teams, and firm performance. Results from a field study with 73 high-technology firms showed that the relationships between the HR practices and firm performance (sales growth and stock growth) were mediated through their top managers' social networks.
\end{abstract}

Researchers in the field of strategic human resource management (SHRM) have increasingly relied on the resource-based view of the firm to explain the role of human resource practices in firm performance (Wright, Dunford, \& Snell, 2001). Indeed, theoretical research on SHRM has suggested that systems of HR practices may lead to higher firm performance and be sources of sustained competitive advantage because these systems of practices are often unique, causally ambiguous, and difficult to imitate (Lado \& Wilson, 1994). However, HR practices can only be a source of sustained competitive advantage when they support resources or competencies that provide value to a firm (Wright et al., 2001). Thus, Wright, Snell, and their colleagues (e.g., Snell, Youndt, \& Wright, 1996; Wright et al., 2001) have argued that SHRM research should identify resources that are critical for advantage in a given competitive context and the HR practices to build and support these resources.

High-technology firms are an important and interesting context in which to study the effects of human resource practices and employee-based resources because such firms play an increasingly important economic role and exist in an environment characterized by rapid change, ambiguity, and hypercompetition (D'Aveni, 1994). These tur-

We would like to thank Patrick Wright, Ken G. Smith, Rose Batt, and Lisa Moynihan for their helpful comments on drafts of this work. We would also like to thank Sara Rynes and our three anonymous reviewers for their valuable comments and suggestions. bulent environmental conditions place a premium on both the speed and the quality of top management team (TMT) decision making and firm action (Eisenhardt, 1989). A key factor in a TMT's ability to achieve both speed and quality is the use of real-time information (Eisenhardt, 1989). The social networks of top managers, defined as the systems of relationships top managers have with employees and other actors outside of their organization, are a chief source of timely and relevant information on the state of both the external environment and the organization. Thus, the distinct information capabilities created though different TMT networks-both external networks and internal networks-may provide a competitive advantage for high-tech firms (Barney, 1991).

In this article, we argue that TMT social networks will be a source of competitive advantage in hightechnology firms. Specifically, we use the information-processing and "boundary-spanning" literatures to develop hypotheses linking TMT social networks and firm performance. Further, we argue that firms may systematically develop and sustain social networks through supportive HR practices. In particular, we hypothesize that a set of networkbuilding HR practices-including mentoring, incentives, and performance appraisals to encourage the development of business relationships-are significantly related to TMT networks. Finally, we predict that TMT networks will mediate the relationship between HR practices and firm performance. We tested our hypotheses in a sample of 73 technology firms. CEOs provided data on HR practices; top management team members provided 
data on networks; and secondary sources provided data on firm performance.

\section{BACKGROUND AND HYPOTHESES}

\section{TMT Social Networks and Firm Performance}

We focus on the networks of top managers because they are an important subset of those employees who have contact both with the employees of their own firm and with important external actors. As such, they are in a particularly favorable position to collect and manage the information that enables organizations to act (Mintzberg, 1973; Thompson, 1967). Information theory (Galbraith, 1973) suggests that organizations need to be able to access and use information in order to reduce uncertainty and take actions to increase performance. Three components of information management lead to effective action under uncertainty: information gathering (from inside and outside a firm), processing, and distribution. Through their unique position at the apex of their organization, top managers are able to affect the information flow within the organization by gathering and redistributing information across key external actors and internal locales. As we argue below, the structure (size and range) and strength of ties of TMT external and internal networks provide informational benefits that lead to competitive advantages and higher firm performance.

In this research, TMT social networks refer to the sets of relationships top managers have with others in their own organization (internal networks) and with individuals outside of the organization who hold information of potential value to the firm (external networks). Importantly, networks differ in size, defined as number of contacts, and range, defined as diversity of contacts (Burt, 1982). Large networks are potentially, but not necessarily, diverse (Granovetter, 1973). For example, a TMT with a customer focus may develop a very large network of contacts with current and potential customers but may have few contacts with other types of actors (financial institutions, suppliers, and competitors, for example). In addition to varying on these dimensions of structure, networks can also vary on the strength of ties between actors. Strong ties are those that are of long duration, exercised frequently, and emotionally close (Granovetter, 1973). Further, if TMT social networks are idiosyncratic because they are created through firm-specific practices, then they can lead to sustainable competitive advantage (Barney, 1991).

Whereas top managers' external networks are potentially a rich source of new information (Keegan,
1984), their internal networks provide opportunities to exploit information their firm already holds. Because Keegan (1984) found TMTs relied heavily on external sources of information, TMTs that also have effective internal networks may provide distinctive advantage to their firms. Top managers are responsible for gathering, sifting, and collating information from different employee groups and departments throughout an organization (Mintzberg, 1973). Thus, TMTs whose external and internal networks are structured to maximize information gathering are better able to provide an information advantage to their organizations. In general, larger networks contain more capacity for information than smaller networks (Burt, 1982; Granovetter, 1973). In addition, networks that contain links to many different types of actors potentially contain more diverse and novel information (Burt, 1982). Thus, TMT networks that are large and diverse in range provide value to a firm in the form of information advantages.

In addition to the size and range of networks, we address the strength of the ties they comprise. Krackhardt (1992) argued that strong ties are desirable because they aid in the development of trust and reciprocity, what he referred to as philos. Philos enables parties to exchange complex information that could not be transferred over weaker links (Hansen, 1999). Additionally, from an information perspective, the critical contingency is the type of information that is required from a network. For technology firms, sensitive and complex information is particularly useful as rivals attempt to gain first-mover advantages through innovation (D'Aveni, 1994). Where information is complex, sensitive, or proprietary, strong ties are required to motivate individual actors to transfer information (Hansen, 1999).

Hypothesis 1. TMT external networks that are large in size, broad in range, and characterized by strong ties will be associated with increased firm performance.

Hypothesis 2. TMT internal networks that are large in size, broad in range, and characterized by strong ties will be associated with increased firm performance.

\section{SHRM and the Development of TMT Social Networks}

While the above discussion suggests that TMT networks are valuable and linked to higher firm performance, it is important to understand how firms can develop and support this organizational resource. Research on strategic human resource 
management suggests that firms can create and support employee-based competencies through HR practices (Wright et al., 2001). Similarly, Leana and Van Buren (1999) argued that HR practices are the primary means by which firms can manage the set of social relationships held by organizational employees.

Research on SHRM suggests that HR practices can enhance firm performance when they are internally aligned with one another to manage employees in a manner that leads to competitive advantage (Delery \& Doty, 1996). Further, the appropriateness of a set of HR practices may depend on the competency that a firm is trying to develop (Snell et al., 1996). HR practices can create value for a firm when the individual practices are aligned to develop critical resources or competencies (Wright et al., 2001). It is important to note that the employeebased capabilities built and sustained through HR practices will be difficult to imitate because these practices and policies may be firm-specific, socially complex, and path-dependent (Lado \& Wilson, 1994). Even if a set of practices can be imitated, there will be a considerable time lag between the implementation of a system and its impact (Wright et al., 2001). Thus, we argue that a system of HR practices can underlie and support the sustainability of the competitive advantage created through TMT networks.

Thus, it is important to identify a set of HR practices that firms can use to systematically develop and manage TMT networks. The performance of a desired behavior (that is, the development of external or internal networks) is a function of ability, motivation, and opportunity (Locke \& Latham, 1990). To elicit desired behaviors from employees, including top managers, firms must provide feedback and incentives that reinforce the desired behaviors (Locke \& Latham, 1990). Performance appraisals and compensation are the primary HR practices firms use to elicit and reinforce desired behaviors (Latham \& Wexley, 1981). Thus, firms should evaluate and compensate top managers for their ability to build and maintain relationships with key external and internal actors. For example, TMT members are more likely to build large and diverse internal networks and to develop strong ties to external constituents if their performance appraisals, incentive compensation, or both are explicitly tied to the development of social relationships with such actors.

Because behavioral outcomes depend on both individual motivation and appropriate skills (Locke \& Latham, 1990), firms should also train TMTs to learn relationship-building skills. The best learning opportunities may come from mentorship or interacting and exchanging ideas with peers (Noe, 2002). For example, TMT members with many years of firmspecific experience can mentor new members on how to develop strong relationships with many different sets of actors. Finally, firms must provide opportunities for performance of desired behaviors (Locke \& Latham, 1990).

Organizations can increase the access TMT members have to external and internal actors by providing them with the time and resources for this task (Cohen \& Prusak, 2001). For example, top managers may be able to develop larger and broader networks if they have budgeted funds for relationship building.

Hypothesis 3. A set of specific networkingbuilding $H R$ practices will be positively related to the size, range, and strength of ties of TMT external networks.

Hypothesis 4. A set of specific network-building HR practices will be positively related to the size, range, and strength of ties of TMT internal networks.

To correctly specify the results of specific networking practices, it is important to control for some general HR practices that may also link to performance. In particular, previous research has pointed to compensation as an important practice for affecting the composition and interactions of top executive teams (Gerhart \& Milkovich, 1990). Indeed, there is evidence that incentive pay based on organization performance is related to financial measures of firm performance (e.g., Gerhart \& Milkovich, 1990) and firm survival (e.g., Welbourne \& Andrews, 1996). Further, incentive pay based on firm performance may indirectly affect the social networks of top managers because it increases commitment to organizational goals, employee cohesiveness, and a collective orientation (Lawler, 1981). Because incentive pay based on organizational performance is likely to be related to firm performance and may have spillover effects on TMT social networks, we directly controlled for this practice in our analyses.

\section{TMT Social Networks as a Mediator of the HR- Firm Performance Relationship}

As discussed above, Wright and his coauthors (2001) argued that human resource practices lead to higher firm performance through their effects on employee-based firm capabilities and resources. In this article, we have argued that a system of specific network-building HR practices can be used to manage the external and internal social networks of top 
managers, and that these employee-based resources should have significant effects on firm performance. Therefore, we expect that one way HR practices affect firm performance is through their effect on TMT social capital.

Hypothesis 5. TMT external and internal social networks will mediate the relationships between sets of HR practices and firm performance.

\section{METHODS}

\section{Sample}

The target population for the study was hightechnology companies in the mid-Atlantic region of the United States. Within each company, we collected (1) a detailed CEO questionnaire to measure HR practices, (2) detailed TMT (excluding CEO) questionnaires to measure social networks, and (3) secondary source records to measure financial performance. This data collection strategy eliminated the possibility of percept-percept bias, because the data for each stage of our model were collected from a different source.

An initial list of companies was identified through the 1998 Mid-AtlanTech Almanac, a regional directory of high-technology firms that provides company profiles and contact information. Because recent initial public offerings (IPOs) may not have been listed in this source, we obtained an additional list of high-technology organizations from a regional high-technology council. Drawing on these two sources, we identified and contacted 211 actively operating high-tech firms. Of the 211 firms contacted, 85 agreed to participate in the study. Usable responses were collected from 73 companies, for a participation rate of 35 percent. We considered a company response to be usable if we received a completed CEO survey and at least one completed top manager survey. Participant firms did not significantly differ from nonparticipants in terms of reported sales $\left(t_{210}=1.36\right.$, n.s. $)$ or number of employees $\left(t_{210}=1.49\right.$, n.s. $)$. The sample represents the full range of technology firms operating in the region, in terms of both number of employees (45 to 16,668$)$ and revenue (\$1.2 million to $\$ 4$ billion). The mean number of employees was 1,742 , with a standard deviation of 3,391 ; the median number of employees was 510.

To ensure consistency across firms, and following the procedure suggested by Finkelstein and Hambrick (1996), we asked the CEO of each firm to identify its top management team, defining the team as those persons typically involved in deciding the large and strategic issues facing the firm. TMTs ranged in size from 2 to 12 members and averaged 5.9 executives. An average of 3.22 top managers responded within each firm, for an overall internal response rate of 54 percent. With the exception of five companies, there were at least two TMT respondents per company. In addition, 67 percent of the companies had three or more responses. Because we did not have a perfect internal response rate for the top manager surveys, we ran several tests to assess the reliability of our network data. We examined ICC(1) statistics to determine whether a significant proportion of the variance of a measure could be explained by membership in a particular TMT (Bliese, 1998; Shrout \& Fleiss, 1979) and ICC(2) statistics to determine the stability of the team-level means (Bliese, 1998). For all internal network measures (range, frequency, duration, and emotional intensity) except size, the results of an analysis of variance (ANOVA) were significant; the ICC(1) and ICC(2) values suggested that the internal executive networks were vastly more similar within TMTs than across them; and the team-level means appeared stable. Thus, our analysis suggest the data were reliable and that missing responses were not creating bias in our findings.

\section{Variable Definition and Measurement}

HR practices. As discussed above, we were interested in the effects of a set of specific networkbuilding practices and wanted to control for the potential effects of incentive pay based on organizational performance. As noted above, measures of HR practices were collected from the CEO of each participating organization because the CEO is likely to be the best source of information about the practices used to manage top executives (Martell, Carroll, \& Gupta, 1992). For example, important HR issues such as hiring, compensation, and training are typically negotiated between a firm's CEO and its board of directors. Following the procedures outlined by Delery and Doty (1996), we "operationalized" the two sets of HR practices as additive indexes.

Incentive pay based on company performance may include bonuses and stock options for which the level of rewards is tied directly to organization performance (Gerhart \& Milkovich, 1990). We based four TMT incentive pay items on earlier SHRM studies (e.g., Delery \& Doty, 1996; see Table 1). Overall, the scale showed good reliability $(\alpha=.74)$.

Above, we argued that specific network-building $H R$ practices would include training, performance assessment, and rewards designed to help and encourage top managers to build relationships with 
TABLE 1

Results of Factor Analysis for Human Resource Practices ${ }^{\mathrm{a}}$

\begin{tabular}{|c|c|c|}
\hline Variable & Component 1 & Component 2 \\
\hline \multicolumn{3}{|l|}{ Incentive pay } \\
\hline $\begin{array}{l}\text { TMT members' variable pay is based on how well the company } \\
\text { as a whole is performing. }\end{array}$ & .76 & .03 \\
\hline $\begin{array}{l}\text { This firm uses multiple incentives (e.g., stock options, signing } \\
\text { bonuses) to attract top candidates for the TMT. }\end{array}$ & .73 & .19 \\
\hline $\begin{array}{l}\text { The majority of TMT members' pay is based on variable } \\
\text { compensation (bonuses, stock, profit sharing, etc.). }\end{array}$ & .69 & .17 \\
\hline \multicolumn{3}{|l|}{ Network-building HR practices } \\
\hline $\begin{array}{l}\text { TMT members are provided expense accounts for developing } \\
\text { job-related personal contacts. }\end{array}$ & .15 & .82 \\
\hline $\begin{array}{l}\text { TMT members have received training to develop personal } \\
\text { relationships with key internal stakeholders. }\end{array}$ & .09 & .81 \\
\hline $\begin{array}{l}\text { TMT members are provided financial incentives for developing } \\
\text { job-related personal relationships with key internal employees. }\end{array}$ & .22 & .77 \\
\hline $\begin{array}{l}\text { In this organization, TMT members are evaluated on their } \\
\text { ability to develop relationships with key external stakeholders. }\end{array}$ & .22 & .72 \\
\hline $\begin{array}{l}\text { In this firm there are incentives for developing job-related } \\
\text { personal relationships with key internal stakeholders. }\end{array}$ & .30 & .68 \\
\hline $\begin{array}{l}\text { TMT members mentor one another on how to cultivate job- } \\
\text { related personal relationships with other employees of this firm. }\end{array}$ & .32 & .56 \\
\hline Eigenvalues & 2.84 & 4.48 \\
\hline
\end{tabular}

${ }^{\text {a }}$ Boldface indicates the factor on which an item primarily loads.

external and internal actors. We generated eight items based on the theory used to develop Hypotheses 3 and 4 (see Table 1 for items), and the scale showed good reliability ( $\alpha=.76$ ). To provide evidence of discriminant validity, we performed a principal components analysis with "varimax" rotation to examine the factor structure of the two sets of HR practices. As shown in Table 1, the incentive pay practices cleanly loaded on one factor, and the network-building HR practices cleanly loaded on a second factor.

External and internal social networks. Characteristics of TMT external and internal networks were collected from surveys of top managers, excluding CEOs. Respondents evaluated the size, range, and strength of ties for their contacts in nine external categories of actors (external board members, suppliers, customers, financial institutions, competitors, alliance partners, government agencies, trade associations, and "other external") and four internal categories (sales and marketing, research and development, production and operations, and "other internal"). Because executives potentially have hundreds of contacts (Mintzberg, 1973), re- spondents were asked to rate the average relationship within each category.

Network size refers to the total number of contacts in a TMT's social network; larger networks comprise more ties. Each TMT member was asked to identify the total number of his or her contacts in each of the nine external and four internal categories. To create a company score for network size, we summed the number of social ties across the external and internal categories for each TMT and divided by the number of respondents.

Network range refers to the diversity of contacts in a TMT's social network. Range has been measured as the number of different groups or actor categories a network accesses (Powell \& Brantley, 1992; Scott, 1991). Range was the proportion of external and internal categories, respectively, to which a TMT was linked by at least one member.

Strength of ties is a multifaceted construct consisting of interaction frequency, relationship duration, and the emotional intensity or closeness of a bond (Granovetter, 1973). Individually, strength of 
ties was measured as the linear combination of the standardized scores of the three components of tie strength. The TMT tie strength score was the average of the respondents' scores. Interaction frequency was measured as the average number of times per month that a TMT member interacted with identified contacts. Relationship duration was measured on the basis of the TMT member's response to the question, "On average, how long have you known these critical contacts?" Emotional intensity was measured directly through TMT members' response to the item, "On average, how close is your relationship with these contacts?" (For both, 1 = "not at all close," and $5=$ "extremely close").

Financial performance. We primarily used COMPUSTAT to collect measures of sales growth and stock performance for the fiscal year that followed the collection of the HR practice and social network data. High-technology firms and analysts view these measures as leading indicators of performance for firms in high-technology industries (Lewis, 2000). Sales growth is an indication of the extent to which customers value the ideas and products a firm is pursuing, and stock returns are an indication of the extent to which investors approve of the firm's actions. Twenty-one of the firms either did not trade their stock publicly (were not public bond issuers) or had been trading their stock for less than one year, so we calculated correlations and regressions with stock returns for a sample of 52 firms. For private firms, we used a one-year lagged self-reported measure of sales growth from the Mid-AtlanTech Almanac. We then collected the self-reported measure for public firms and found it was highly correlated with the COMPUSTAT data $(r=.94)$, suggesting that it was a reliable measure of sales growth.

Firm size as control variable. According to the resource-based view, firms with superior resources will be able to conceive of and implement unique strategies that rivals will find difficult to emulate (Barney, 1991). Because large firms have more such resource advantages than do small firms, we included firm size as a control. We measured firm size as the natural logarithmic transformation of the number of full-time employees (Kimberly, 1976).

\section{RESULTS}

Table 2 reports the means, standard deviations, and correlations of all variables. We used hierarchical regression analysis to test the hypotheses since this procedure allowed us to test for mediation and control for firm size and TMT incentive pay (entered in step 1 of regressions). Tables 3 and 4 give regression analysis results.

\section{Hypotheses 1 and 2: TMT Social Networks and Firm Performance}

As shown in model 1 of Table 3, which reports the results of the regression analysis of the relationships between TMT networks and firm performance, the range of external networks was significantly related to sales growth $(\beta=0.23, p<.05)$

TABLE 2

Correlations, Means, and Standard Deviations ${ }^{\mathrm{a}}$

\begin{tabular}{|c|c|c|c|c|c|c|c|c|c|c|c|c|c|}
\hline Variable & Mean & s.d. & 1 & 2 & 3 & 4 & 5 & 6 & 7 & 8 & 9 & 10 & 11 \\
\hline 1. TMT incentive pay & 3.31 & 0.69 & & & & & & & & & & & \\
\hline $\begin{array}{l}\text { 2. Network-building HR } \\
\text { practices }\end{array}$ & 2.74 & 0.89 & $.29 * *$ & & & & & & & & & & \\
\hline 3. External network size & 72.79 & 55.91 & $.23^{*}$ & $.37 * *$ & & & & & & & & & \\
\hline $\begin{array}{l}\text { 4. External network } \\
\text { strength of ties }\end{array}$ & 0.10 & 0.71 & .18 & $.42^{* *}$ & $.30 * *$ & & & & & & & & \\
\hline 6. Internal network size & 39.56 & 36.08 & $.23^{*}$ & $.44^{* *}$ & $.39 * *$ & $.28^{* *}$ & $.39 * *$ & & & & & & \\
\hline $\begin{array}{l}\text { 7. Internal network } \\
\text { strength of ties }\end{array}$ & 0.30 & 0.70 & $.34^{*}$ & $.48^{* *}$ & .13 & $.35^{*}$ & $.38^{*}$ & $.22^{*}$ & & & & & \\
\hline 8. Internal network range & 0.81 & 0.20 & .18 & $.32 * *$ & $.23^{*}$ & $.40 * *$ & $.42^{* *}$ & $.43^{* *}$ & $.51 * *$ & & & & \\
\hline 9. Sales growth & 0.33 & 0.71 & $.19^{*}$ & $.21^{*}$ & .17 & $.31 * *$ & $.23^{*}$ & $.28^{* *}$ & .12 & .18 & & & \\
\hline 10. One-year stock returns & 1.44 & 8.42 & $.27^{*}$ & $.29^{*}$ & .06 & $.28^{*}$ & $.31^{*}$ & $.25^{*}$ & -.09 & $.29^{*}$ & $.29^{*}$ & & \\
\hline
\end{tabular}

\footnotetext{
a The value of $n$ is 73 for all correlations except one-year stock return, for which $n$ is 52 .

${ }^{*} p<.05$

${ }^{* *} p<.01$
} 
TABLE 3

Results of Regression Analysis of Relationships with Firm Performance ${ }^{\mathrm{a}}$

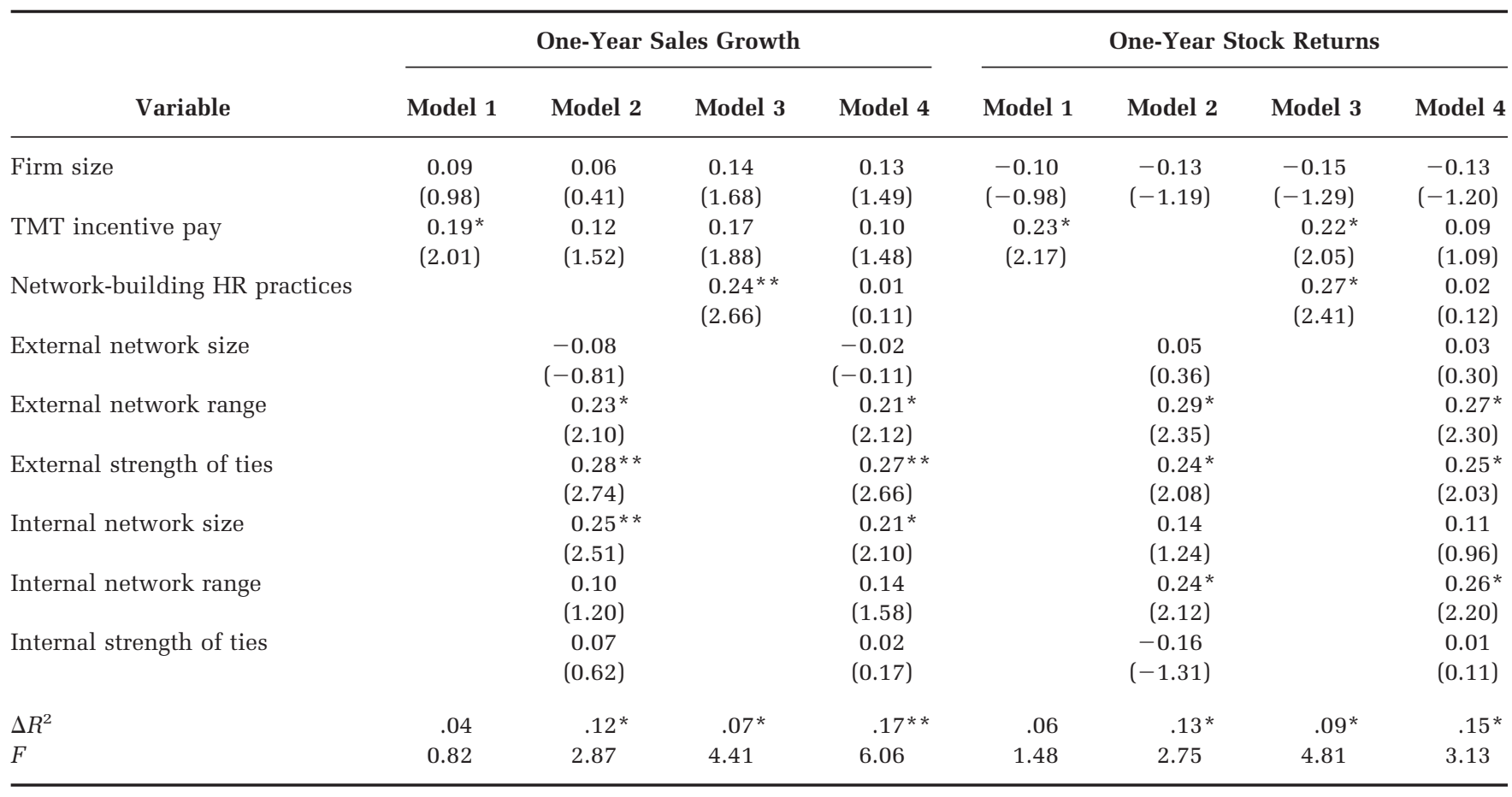

${ }^{\text {a }}$ Standardized coefficients are reported, with $t$-values in parentheses. $n=73$ for sales growth, $n=52$ for stock returns.

${ }^{*} p<.05$

${ }^{* *} p<.01$

and stock returns $(\beta=0.29, p<.05)$. The strength of ties of external networks was significantly related to sales growth $(\beta=0.28, p<.01)$ and stock returns $(\beta=0.24, p<.05)$. External network size was not significantly related to either measure of firm performance. In addition, internal network size was significantly related to sales growth $(\beta=$ $0.25, p<.01)$ but not stock returns $(\beta=0.14$, n.s.). The range of internal networks was significantly related to stock returns $(\beta=0.24, p<.05)$ but not sales growth ( $\beta=0.10$, n.s.). The strength of ties of internal networks was not significantly related to either measure of firm performance (sales growth, $\beta=0.07$, n.s.; stock returns, $\beta=-0.16$, n.s.). Thus, we found partial support for relationships stated in Hypotheses 1 and 2.

\section{Hypotheses 3 and 4: Network-Building HR Practices and TMT Networks}

Table 4 gives the results of our regression analysis of the relationships between network-building HR practices and TMT networks. The HR practices were significantly related to the size of TMT external networks $(\beta=0.34, p<.01)$ and the strength of ties in TMT external networks $(\beta=0.36, p<.01)$, but these practices were not significantly related to TMT external network range $(\beta=0.11$, n.s.). As shown in Table 4, network-building HR practices were significantly related to all three measures of internal networks (size, $\beta=0.34, p<.01$; range, $\beta=0.29, p<.01$; strength of ties, $\beta=0.41, p<$ $.01)$. Thus, our results suggest that specific network-building practices may be an effective means for firms to purposefully manipulate the networks of their top managers.

\section{Hypothesis 5: TMT Networks as a Mediator of the HR-Firm Performance Relationship}

We tested for mediation following the three-step procedure outlined by Baron and Kenny (1986). In step 1 (Table 3, model 2), we found significant relationships between the set of network-building HR practices and both sales growth $(\beta=0.24, p<$ $.01)$ and stock returns $(\beta=0.27, p<.05)$. In step 2 , we found significant relationships between the HR practices and external and internal TMT networks (see the results presented above). Finally, in the presence of TMT social networks, network-building HR practices were no longer significantly re- 
TABLE 4

Relationship between HR Practices and TMT Networks ${ }^{\mathrm{a}}$

\begin{tabular}{|c|c|c|c|c|c|c|}
\hline \multirow[b]{2}{*}{ Variable } & \multicolumn{2}{|c|}{ Size } & \multicolumn{2}{|c|}{ Range } & \multicolumn{2}{|c|}{ Strength of Ties } \\
\hline & Model 1 & Model 2 & Model 3 & Model 4 & Model 5 & Model 6 \\
\hline Firm size & $\begin{array}{c}0.03 \\
(0.41)\end{array}$ & $\begin{array}{c}-0.04 \\
(-0.34)\end{array}$ & $\begin{array}{c}0.12 \\
(1.17)\end{array}$ & $\begin{array}{c}0.14 \\
(1.27)\end{array}$ & $\begin{array}{c}0.17 \\
(1.58)\end{array}$ & $\begin{array}{c}0.18 \\
(1.53)\end{array}$ \\
\hline TMT incentive pay & $\begin{array}{c}0.24^{*} \\
(2.28)\end{array}$ & $\begin{array}{c}0.21^{*} \\
(2.16)\end{array}$ & $\begin{array}{c}0.24^{*} \\
(2.39)\end{array}$ & $\begin{array}{c}0.21^{*} \\
(2.18)\end{array}$ & $\begin{array}{c}0.13 \\
(1.14)\end{array}$ & $\begin{array}{c}0.10 \\
(0.98)\end{array}$ \\
\hline$\Delta R^{2}$ & $.07^{*}$ & $.08^{* *}$ & $.07^{*}$ & .01 & .05 & $.16^{* *}$ \\
\hline$\Delta F$ & 2.94 & 4.13 & 2.89 & 0.63 & 2.16 & 11.48 \\
\hline \multicolumn{7}{|l|}{ Internal networks } \\
\hline$\Delta R^{2}$ & .04 & $.14^{* *}$ & .03 & $.08 * *$ & $.11 * *$ & $.13^{* *}$ \\
\hline$F$ & 1.74 & 8.47 & 1.54 & 4.09 & 4.02 & 5.22 \\
\hline
\end{tabular}

${ }^{\text {a }}$ Standardized coefficients are reported, with $t$-values in parentheses; $n=73$.

$* p<.05$

$* * p<.01$

lated to either measure of firm performance (Table 3 , model 3). Indeed, the $t$-values for the relationships between the HR practices and firm performance drop dramatically, suggesting full mediation. Thus, we found strong support for Hypothesis 5: HR practices for TMT network development appear to affect firm performance through TMT external and internal social networks.

\section{Practical Effects}

Importantly, the effects are also meaningful from a practical and financial standpoint. Further, the network-building HR practices and incentive pay based on organizational performance had similar practical effects. Regarding the direct effects of HR practices on performance, our results showed that a one-standard-deviation increase in specific network-building practices yielded an 18.7 percent growth in sales and a 2.55 percent stock return, and a one-standard-deviation increase in incentive pay based on organizational performance yielded a 17.2 percent growth in sales and a 2.93 percent stock return. However, it is important to note that the mediating effects of TMT networks accounted for nearly all of the effect of network-building practices on sales growth but less than half of the effect of incentive pay practices based on organizational performance.

\section{DISCUSSION}

This study was motivated by a desire to understand the role of human resource practices in creating sustainable competitive advantage. In general, our results supported the notion that one way HR practices lead to higher firm performance is through developing and reinforcing employeebased resources that are valuable in a particular competitive environment (e.g., Wright et al., 2001). We found that a set of specific network-building HR practices was significantly related to the valuable firm resource of TMT social networks. Indeed, network-building HR practices were significantly related to all of the measured elements of the TMT networks except external range. Further, we found that the set of network-building HR practices led to higher firm performance (measured as both sales growth and stock performance) through the practices' effect on the external and internal social networks of top management teams. Thus, our results suggest that future strategic human resource management research should continue to examine employee-based and other firm capabilities that 
may act as mediating links between HR practices and performance.

Although our hypotheses focused on links between specific network-building HR practices and TMT networks, the findings suggest there may be multiple methods by which firms can develop and manage top manager networks. Indeed, we found that the use of TMT incentive pay based on organizational performance was significantly related to external TMT network size and internal TMT network size and strength. These relationships may not be surprising. For example, Hambrick (1995) argued that greater use of TMT incentive pay based on organizational rather than unit performance should create greater cooperation between executives. Such cooperation may aid in the development of executive networks. Thus, SHRM researchers should look to identify multiple sets of HR practices that can be used to develop employeebased resources such as TMT social networks. For example, future researchers may look at the effects of specific recruitment and selection actions on the development of TMT networks.

While there may be several ways for organizations to build the resource of TMT networks, our results suggest that specific, targeted HR practices may be more effective than general practices (that is, performance-based incentive practices). Specifically, the relationships between specific networkbuilding practices and firm performance were larger than those between performance-based incentive practices and firm performance. This pattern was especially clear when we examined the indirect effects of the two sets of practices on (1) sales growth (for targeted HR practices, $\beta=0.22$, incentive pay, $\beta=0.10$ ) and (2) stock returns (targeted HR practices, $\beta=0.23$, incentive pay, $\beta=$ 0.15). These findings suggest that firms should use specific sets of HR practices if they are trying to develop and reinforce a particular employee-based resource or competency. However, we did find large, direct, practical effects for the link between incentive pay based on organizational performance and both sales growth and stock returns. Thus, general sets of HR practices (such as pay based on organizational performance) affect performance, but they may do so in ways other than affecting employee-based resources.

This study also supported the notion that top managers' social networks are important for firm performance. Whereas strong and diverse TMT external networks increased both sales growth and stock price, large external networks did not. Thus, external actors may be willing to share critical information only when ties are close and trusting. Moreover, diverse ties may provide access to novel information, and close ties may allow for the understanding needed for effective transfer when information is complex. Overall, TMTs may wish to selectively build strong, trusting relationships with a range of external actors, rather than build large networks. Since range and strength theoretically provide different but complementary capabilities, it would be of value to explore interactions, threshold levels, and the possibility of combined effects.

Large and diverse internal TMT networks were related to firm performance, but strong ties were not. The data suggest that a high level of connectedness internally allows a TMT to become aware of information reservoirs and the information needs of various organizational locales. The TMT can then facilitate the exchange of information within its firm and become better able to seek relevant information from external contacts. Because membership in an organization usually creates a nominal threshold level of trust and goal congruence, strong internal ties may not be necessary for accessing and transferring information internally.

Although our results are important, there are several limitations to their generalizability. First, the hypotheses were tested on a relatively small sample of firms; thus, our power to detect smaller effects was limited. For example, the direct link between performance-based incentive practices and firm performance found in previous studies was not significant here, when TMT network measures were also present. However, we must warn against concluding that TMT networks fully mediate this relationship. Note that the direct path $t$-values for incentives in the mediated regression analysis would probably be statistically significant in a larger sample.

Second, while the relationships may be predictive for similar types of firms, and environmental turbulence appears to be increasing in most sectors, it is unclear if this same model would be predictive with a sample of low-technology or regulated firms, whose environments are less dynamic. Under conditions of uncertainty and turbulence, firms may gain considerable advantage by acting early and often on the basis of information superiority. However, firms facing less dynamic environments may use networks differently. For example, defense contractors operating in a regulated environment may use the influencing capabilities of TMT networks, such as lobbying, to gain advantage when bidding on government contracts. Consequently, future research should examine a broader range of organizations to identify potential moderators of the relationship between networks and firm performance. 
Third, this research is an incomplete test of the role of HR practices in building competitive advantage. In particular, we only examined HR practices for a relatively idiosyncratic set of organizational employees. There are many different groups of employees inside organizations that can create competitive advantage (Lepak \& Snell, 1999); thus, future research should examine how HR practices affect firm resources that are developed around other employees besides top managers.

We also note several limitations that may have led to the overestimation of effect sizes for the relationships between the variables in the study. For example, the research was a field study in which the survey measures of HR practices and social capital were collected concurrently; thus, it is not possible to prove causality between constructs. Future research should focus on collecting longitudinal data to test the predictive relationship between the independent and mediating variables. Our results are also potentially biased because we had a single respondent report the HR practices of each firm (Gerhart, Wright, McMahan, \& Snell, 2000). This problem may be mitigated by the fact that the raters (the CEOs) who assessed the practices for small sets of employees had direct knowledge about how these employees were managed (Gerhart et al., 2000). Those conducting future research should test the robustness of our findings by collecting measures of HR practices from multiple respondents.

In addition, although this study goes further than other studies in examining potential mediators of the link between HR practices and firm performance, important variables remained unmeasured in our study. In particular, future research should examine the potential mediators between HR practices and networks (such as high levels of collective goal orientation and access) and between networks and firm performance (access to valuable information and transfer of information, for instance). Similarly, we did not control for a number of general high-performance practices that may be related to both firm performance and specific networking practices. For example, by asking about training and performance assessment for networking, we may have been picking up on general "high-commitment practices" (Delery \& Doty, 1996) of internal development. Thus, our findings for the specific networking practices may be overstated. Future research is necessary to determine the extent to which specific HR practices affect firm performance and mediators above and beyond the effects of general high-performance practices.

Overall, this study contributes to the literatures on strategic human resource management and social networks in several ways. First, we begin to look into the black box enclosing the interface between HR practices and firm performance by providing evidence that a set of network-building HR practices is significantly related to firm performance through TMT networks. The study also provides evidence that multiple sets of HR practices may exist inside firms for the same set of employees. Importantly, our findings suggest that specific and general HR practices affect firm performance in different ways-specific practices seem to affect performance by building and reinforcing a specific employee-based capability, whereas general practices may affect performance more broadly through other factors such as employee skills or motivation. Therefore, SHRM researchers should be careful to base their identification of sets of HR practices on the mediators that they are interested in studying. The study also provides evidence that both external and internal networks serve as important informational resources for high-technology firms. From a practical standpoint, it appears that firms may be able to purposefully develop and manage the networks of their top managers. However, since different network characteristics affect firm performance differently, companies should be careful to create the network characteristics that are most likely to affect performance in their particular environmental context.

\section{REFERENCES}

Barney, J. 1991. Firm resources and sustained competitive advantage. Journal of Management, 17(1): 99120.

Baron, R. M., \& Kenny, D. A. 1986. The moderator-mediator variable distinction in social psychological research: Conceptual, strategic, and statistical considerations. Journal of Personality and Social Psychology, 51: 1173-1182.

Becker, B., \& Huselid, M. A. 1998. High performance work systems and firm performance: A synthesis of research and managerial implications. In G. R. Ferris (Ed.), Research in personnel and human resources management, vol. 16: 53-101. Greenwich, CT: JAI Press.

Bliese, P. D. 1998. Team size, ICC values, team-level correlations: A simulation. Organizational Research Methods, 1: 355-373.

Burt, R. S. 1982. Towards a structural theory of action. New York: Academic Press.

Cohen, D., \& Prusak, L. 2001. In good company: How social capital makes organizations work. Boston: Harvard Business School Press. 
D'Aveni, R. A. 1994. Hypercompetition: Managing the dynamics of strategic maneuvering. New York: Free Press.

Delery, J. E. 1998. Issues of fit in strategic human resource management: Implications for research. $\mathbf{H u}-$ man Resource Management Review, 8: 289-309.

Delery, J. E., \& Doty, D. H. 1996. Modes of theorizing in strategic human resource management: Tests of universalistic, contingency, and configurational performance predictions. Academy of Management Journal, 39: 802-835.

Eisenhardt, K. M. 1989. Making fast strategic decisions in high-velocity environments. Academy of Management Journal, 32: 543-577.

Finkelstein, S., \& Hambrick, D. C. 1996. Strategic leadership: Top executives and their effects on organizations. St. Paul: West.

Galbraith, J. 1973. Designing complex organizations. Reading, MA: Addison-Wesley.

Gerhart, B., \& Milkovich, G. T. 1990. Organizational differences in managerial compensation and financial performance. Academy of Management Journal, 33: 663-691.

Gerhart, B., Wright, P. M., McMahan, G. C., \& Snell, S. A. 2000. Measurement error in research on human resources and firm performance: How much error is there and how does it influence effect size estimates? Personnel Psychology, 53: 803-834.

Granovetter, M. 1973. The strength of weak ties. American Journal of Sociology, 78: 1360-1380.

Hambrick, D. 1995. Fragmentation and the other problems CEOs have with their top management teams. California Management Review, 37(3): 110-127.

Hansen, M. 1999. The search-transfer problem: The role of weak ties in sharing knowledge across organizational subunits. Administrative Science Quarterly, 44: 82-111.

Keegan, W. J. 1984. Multinational scanning: A study of the information sources utilized by headquarters executives in multinational companies. Administrative Science Quarterly, 29: 411-421.

Kimberly, J. 1976. Organizational size and the structuralist perspective. Administrative Science Quarterly, 21: 571-597.

Krackhardt, D. 1992. The strength of strong ties: The importance of philos in organizations. In N. Nohria \& R. Eccles (Eds.), Networks and organizations: Structure, form, and action: 216-239. Cambridge, MA: Harvard University Press.

Lado, A. A., \& Wilson, M. C. 1994. Human resource systems and sustained competitive advantage: A competency-based perspective. Academy of Management Review, 19: 699-727.

Latham, G. P., \& Wexley, K. N. 1981. Increasing produc- tivity through performance appraisal. Reading, MA: Addison-Wesley.

Lawler, E. E. 1981. Pay and organization performance. Reading, MA: Addison-Wesley.

Leana, C. R., \& Van Buren, H. J. 1999. Organizational social capital and employment practices. Academy of Management Review, 24: 538-555.

Lepak, D. P., \& Snell, S. A. 1999. The human resource architecture: Toward a theory of human capital allocation and development. Academy of Management Review, 24: 31-48.

Lewis, M. 2000. The new new thing: A Silicon Valley story. New York: Norton.

Locke, E. A., \& Latham, G. P. 1990. A theory of goalsetting and task performance. Englewood Cliffs, NJ: Prentice-Hall.

Martell, K., Carroll, S. J., \& Gupta, A. K. 1992. What executive human resource management practices are most effective when innovativeness requirements are high? In L. R. Gomez-Mejia \& M. W. Lawless (Eds.), Advances in global high-technology management, vol. 1: 3-30. Greenwich, CT: JAI Press.

Mintzberg, H. 1973. The nature of managerial work. New York: Harper \& Row.

Noe, R. A. 2002. Employee training and development. Boston: McGraw-Hill Irwin.

Powell, W. W., \& Brantley, P. 1992. Competitive cooperation in biotechnology: Learning through networks? In N. Nitin \& R. Eccles (Eds.), Networks and organizations: 366-394. Boston: Harvard Business School Press.

Scott, J. 1991. Social network analysis: A handbook. London: Sage.

Shrout, P. E., \& Fleiss, J. L. 1979. Intraclass correlations: Uses in assessing rater reliability. Psychological Bulletin, 86(2): 420-428.

Snell, S. A., Youndt, M. A., Wright, P. M. 1996. Establishing a framework for research in strategic human resource management: Merging resource theory and organizational learning. In G. R. Ferris (Ed.), Research in personnel and human resource management, vol. 14: 61-90. Greenwich, CT: JAI Press.

Thompson, J. D. 1967. Organizations in action. New York: McGraw-Hill.

Welbourne, T. M., \& Andrews, A. O. 1996. Predicting the performance of initial public offerings: Should human resource management be in the equation? Academy of Management Journal, 39: 891-919.

Wright, P. M., Dunford, B. B., \& Snell, S. A. 2001. Human resources and the resource-based view of the firm. Journal of Management, 27: 701-721. 


\section{$-M$}

Christopher J. Collins (cjcornell.edu) is an assistant professor of human resource studies in the College of Industrial and Labor Relations at Cornell University. He received his Ph.D. in organizational behavior and human resources from the Robert H. Smith School of Business at the University of Maryland. His research interests include strategic human resource management, firm innovation and knowledge creation, employee recruitment, and employment brand equity.
Kevin D. Clark is an assistant professor of strategic management in the College of Commerce and Finance at Villanova University. He received his Ph.D. in strategic management from the University of Maryland. His research has investigated top management team decision making in turbulent environments, the role of top management team social networks in performance, and determinants of innovation and knowledge creation in technology firms. 
Copyright of Academy of Management Journal is the property of Academy of Management and its content may not be copied or emailed to multiple sites or posted to a listserv without the copyright holder's express written permission. However, users may print, download, or email articles for individual use. 